Jurnal Penelitian dan Evaluasi Pendidikan

418 - Jurnal Penelitian dan Evaluasi Pendidikan Tahun 16, Nomor 2, 2012 


\title{
EVALUASI EFEKTIVITAS UNIT PRODUKSI DALAM MEMPERSIAPKAN KOMPETENSI KERJA SISWA SMK
}

\author{
Adi Sutopo \\ Staf Pengajar FT Universitas Negeri Medan) \\ Adisutopo51@yahoo.com
}

\begin{abstract}
Abstrak
Tujuan penelitian ini adalah mengetahui: 1) keefektifan kegiatan belajar mengajar; 2) peningkatan kemampuan kompetensi kerja siswa; 3) pemanfaatan faktor pendukung dan mengatasi faktor penghambat unit produksi (UP), serta dampaknya bagi SMK. Model penelitian menggunakan CIPP-Logic dengan mixed method designs. Populasi penelitian adalah SMKN RSBI-SBI rumpun teknologi yang memiliki unit produksi. Penentuan sampel dengan purposive sampling yaitu: SMKN 2 Yogyakarta, SMKN 2 Depok Sleman, SMKN 2 Pengasih Kulon Progo dan SMKN 2 Wonosari Gunung Kidul. Pengumpulan data menggunakan kuesioner, wawancara, observasi dan dokumentasi. Analisis data meliputi analisis deskriptif, model Miles-Huberman dan logical framework analysis. Hasil penelitian adalah: 1) sebagian besar UP aktif, namun sumbangan sebagai sarana pembelajaran dan sumber pembiayaan operasional relatif kecil; 2) sebagian besar program UP mampu menyelaraskan program kurikulum, namun pemanfaatan sarpras dan SDM belum optimal; 3) peningkatan pengetahuan dan keterampilan siswa tercapai, namun jumlahnya terbatas; 4) keefektifan sebagai sarana pembelajaran tercapai, namun jumlah siswa dan guru yang terlibat relatif kecil; 5) kualitas konstruksi dan bahan tinggi serta harga jual standar, namun kualitas tampilan belum maksimal; 6) menambah kesejahteraan warga sekolah, dan pendapatan sekolah; dan 7) sebagian besar UP dipercaya masyarakat/industri.
\end{abstract}

Kata kunci: unit produksi, kemampuan kompetensi kerja, sekolah menengah kejuruan 


\title{
AN EVALUATION OF THE EFFECTIVENESS OF PRODUCTION UNITS IN PREPARING STUDENTS' OCCUPATIONAL COMPETENCE ON VOCATIONAL HIGH SCHOOLS
}

\author{
Adi Sutopo \\ Staf Pengajar FT Universitas Negeri Medan \\ Adisutopo51@yahoo.com
}

\begin{abstract}
This study aims to know: 1) the effectiveness teaching and learning; 2) the improvement of students' occupational competence, 3) the utilization of the facilitating factors and the hindering factors in the production units, and the impacts of the production units on VHSs. The research model used was the CIPP-Logic evaluation model with the mixed method designs. The research population comprised VHSs in the engineering cluster possessing production units in Yogyakarta Special Territory. The research sample was determined purposely, consisting of SMKN 2 Jetis Yogyakarta, SMKN 2 Depok Sleman, SMKN 2 Pengasih and SMKN 2 Wonosari. The quantitative and qualitative data were collected through questionnaires, in-depth interviews, in-depth observations, and documents with reference. The data analysis employed a model by Miles-Huberman and logical framework analysis. The research findings are as follows. 1) Most of the production units are active, but their contributions as learning resources and as operational cost sources are relatively small. 2) Most of the production units are capable of adjusting the curricular programs to the production unit programs, but the utilization of the infrastructure facilities and human resources is not maximal. 3) improving students' knowledge and skills is reached but limited in number, 4) The effectiveness as learning resources for students is reached, but the students and teachers involved are limited in number. 5) The quality of construction and materials is high, the price is standard, but their performance is not maximum yet. 6) The production units can improve the welfare of school members and give the schools additional incomes. 7) Most of the production units are trusted bye industries and society.
\end{abstract}

Keywords: production units, occupational competence, vocational high schools 


\section{Pendahuluan}

Pendidikan adalah salah satu cara untuk meningkatkan kualitas sumber daya manusia (SDM) (Almasi Syahza, 2006:6). Sumber daya manusia yang berkualitas diperlukan untuk mengolah sumber daya alam yang tersedia, agar memiliki nilai ekonomi tinggi dan berdaya saing. Simbolon (2009) mengatakan "SDM merupakan salah satu faktor kunci dalam reformasi ekonomi yakni bagaimana menciptakan sumber daya yang berkualitas dan memiliki keterampilan serta berdaya saing tinggi dalam persaingan global".

Direktur Pembinaan SMK (2006: 3) menyatakan diperlukan sumber daya manusia yang memiliki keunggulan kompetitif dan komperatif bagi pembangunan sektor industri dan sektor ekonomi. Untuk itu dibutuhkan tenaga kerja profesional, khususnya tenaga kerja yang terlibat langsung dalam proses produksi (Wardiman, 1998). Oleh karena itu bila lulusan SMK memiliki kesiapan akan menjadi aset ekonomi yang besar (Suyanto, 2010).

Permasalahan pendidikan kejuruan adalah: (1) kurangnya hubungan antara sekolah dan dunia kerja sehingga membuat siswa kurang termotivasi di sekolah dan kurang cekatan dengan indikasi kerja yang lambat; (2) siswa menyelesaikan sekolah tetapi tidak memiliki keterampilan yang cukup untuk masuk ke pasar kerja; dan (3) pasar kerja semakin banyak membutuhkan orang yang mampu untuk berfikir kompleks, teamwork yang solid, dan mampu belajar untuk bekerja, Neumark dan Allen ( 2003). Demikian halnya dengan Depdiknas (2009) menyebutkan bahwa trend isu yang ada pada pendidikan kejuruan adalah:

Data trend bidang kreatif belum sabih; (b) kemitraan dengan industri dalam penyusunan kurikulum belum optimal dilakukan; (c) dukungan sumber daya bagi implementasi peningkatan kualitas SMK yang mendukung penciptaan kreativitas dan kewirausahaan belum berimbang antara dukungan berupa sarana dan non sarana; (d) data kebutuban dunia usaha, dunia industri, dan ekonomi kreatif belum sabih dan bersifat global; (e) kemitraan dunia usaba, dunia industri dalam dan luar negeri dengan SMK masib rendab; (f) 
ketenagaan (PTK) yang mendukung SMK masih sangat terbatas; (g) dukungan dana dan kebijakan yang bersifat affirmative belum optimal; dan (b) sistem pembelajaran/permagangan belum optimal.

Permasalahan lain dalam pendidikan kejuruan seperti disebutkan Dikmenjur (2007) yaitu: (a) relevansi dan mutu pendidikan menengah kejuruan masih rendah; (b) akses terhadap pelayanan pendidikan menengah kejuruan belum memadai dan; (c) manajemen pendidikan masih belum efisien. Sementara itu jumlah SMK dan siswanya terus meningkat, pada tahun 2007 persentasenya dibandingkan SMA telah mencapai 41:59 dan didorong hingga mencapai 70:30 di tahun 2015 (Dikmenjur, 2007). Hal ini menyebabkan permasalahan dalam praktek kerja industri yaitu kecukupan industri pasangan, karena perkembangan jumlah industri tidak secepat perkembangan SMK. Permasalahan tersebut menunjukkan bahwa sarana dan prasarana SMK sebagian besar belum sesuai dengan kebutuhan, belum adanya link and match antara dunia pendidikan dan dunia industri/usaha, sehingga lulusan sekolah kejuruan kurang kompeten sesuai kebutuhan industri baik dalam keterampilan kerja maupun keterampilan sosial.

Upaya mengatasi pendidikan kejuruan tersebut yaitu dengan revitalisasi peralatan SMK (Joko Sutrisno, 2009), pengembangan kelengkapan alat-alat praktek, pendidikan kewirausahaan, menjalin kerjasama dengan industri (Suyanto, 2010), program link and match (Wardiman, 1998:66), serta mendirikan unit produksi (Dikmenjur, 2005). Unit produksi sebagai program sekolah berfungsi untuk mengatasi permasalahan dana operasional, peningkatan kesejahteraan guru dan karyawan, melatih kemampuan psikomotorik, kognitif, dan afektif (Subiyanto, 2008), (Slamet PH, 2008), (Wardiman, 1998). Dengan demikian unit produksi di SMK diharapkan memiliki peran ganda yaitu sebagai tempat melatih keterampilan siswa dan guru, serta sebagai penghasil sumber pembiayaan sekolah.

Berdasarkan hasil penelitian Martubi dan Satunggalno (1998) tentang model penyelenggaraan UPJ di SMK DIY menyimpulkan bahwa: (a) pemahaman warga sekolah tentang UP masih kurang dan pemasyarakatannya belum sampai pada tingkatan yang diharapkan, 
yaitu belum mengarah pada pemasyarakatan usaha sebagaimana mestinya, (b) kegiatan UP belum direncanakan dengan baik, masih berjalan secara insidental, dan (c) hambatan dominan yang muncul adalah dari faktor SDM yang kurang profesional sebagai pengusaha (kultur, profesi, orientasi). Demikian halnya hasil penelitian Sri Lestari (2010) menyimpulkan bahwa hambatan dalam pelaksanaan unit produksi di SMK adalah: (a) waktu pelaksanaan unit produksi di SMK ini masih relatif kurang, (b) kurikulum pembelajaran di sekolah belum sesuai, (c) keterbatasan alat, (d) persaingan dengan industri, dan (e) hubungan dengan pasar atau konsumen menjadi kurang baik. Hal ini menunjukkan bahwa pelaksanaan UPJ masih banyak mengalami kendala, sehingga UPJ belum mampu berjalan sesuai tujuan.

Berbeda halnya dengan hasil penelitian Silvi Intriani (2009) yang menyimpulkan bahwa unit produksi memiliki peran yang besar dalam menumbuhkan belajar berwirausaha yang meliputi sikap percaya diri, menumbuhkan keberanian mengambil resiko, melatih kepiawaian berkreasi, cara pikir berorientasi ke masa depan, dan melatih kejujuran serta ketekunan. Hasil penelitian ini menunjukkan bahwa kegiatan unit produksi menjadi sarana melatih kewirausahaan secara langsung pada siswa SMK.

Demikian halnya penelitian Iwa Kuntadi (2011) terhadap pelaksanaan UPJ di BLPT Bandung menyebutkan bahwa organisasi dan mekanisme pengelolaan unit produksi telah berjalan dengan baik, mutu hasil pekerjaan termasuk baik, dan kegiatan unit produksi memiliki relevansi dengan praktek kejuruan di SMK. Berdasarkan hasil penelitian ini menunjukkan bahwa kegiatan unit produksi apabila dikelola dengan baik dapat menghasilkan barang atau jasa yang dibutuhkan masyarakat dan memberikan pengalaman kerja siswa karena memiliki relevansi dengan kurikulum yang berlaku.

Berdasarkan permasalahan yang dihadapi SMK dalam menyiapkan kemampuan kompetensi kerja siswa serta hasil penelitian terhadap pelaksanaan unit produksi sebelumnya di atas menunjukkan bahwa unit produksi memiliki peranan yang penting bagi SMK. Selain itu sampai saat ini unit produksi masih menjadi program yang diunggulkan SMK untuk meningkatkan kualitas lulusan dan menarik simpati masyarakat dalam 
menyekolahkan putra-putrinya di SMK, namun dalam pelaksanaan dan pengembangan unit produksi secara umum belum mencapai tujuan seperti yang diharapkan. Oleh karena itu peran unit produksi sebagai salah satu tempat pembelajaran siswa dan guru, serta sebagai sumber pendapatan sekolah perlu digali yaitu: (a) bagaimana pelaksanaan unit produksi dalam meningkatkan kemampuan kompetensi siswa; (b) faktor apa sajakah yang menjadi penghambat dan pendukung; (c) sejauh mana unit produksi mampu menghasilkan produk/jasa yang berkualitas dan berdaya saing; dan (d) bagaimana dampak unit produksi bagi SMK.

Secara umum tujuan penelitian ini adalah untuk mengetahui pelaksanaan unit produksi di SMK rumpun teknologi dalam meningkatkan kemampuan kompetensi kerja siswa. Adapun tujuan khususnya untuk mengetahui efektivitas kegiatan belajar mengajar, peningkatan nilai tambah input, pemanfaatan faktor pendukung dan mengatasi faktor penghambat, dan dampak pelaksanaan unit produksi bagi SMK.

Secara teoritis, hasil penelitian ini bermanfaat untuk memberi masukan dalam mengkaji pengembangan unit produksi sebagai: bagian sekolah terpadu, menghasilkan lulusan berkualitas dan hidup mandiri, industri profit. Secara praktis hasil penelitian ini bermanfaat untuk pengembangkan program unit produksi agar: (a) lebih efektif sebagai sumber belajar, (b) membentuk siswa mampu hidup mandiri, (c) menjadi tempat praktek kerja industri, (d) menghasilkan sumber pembiayaan sekolah, dan (e) meningkatkan kualitas produk atau jasa.

\section{Metode Penelitian}

Penelitian ini termasuk jenis penelitian evaluasi yang meliputi: effort evaluation, Process evaluation dan treatment specification approach. Metode penelitian evaluasi ini menggunakan mixed method designs dengan concurrent triangulation designs (Creswell, 2009: 213).

Populasi penelitian adalah SMKN RSBI-SBI rumpun Teknologi di DIY yang memiliki unit produksi aktif. Penentuan sampel penelitian berdasarkan purposive sampling yaitu di SMKN RSBI-SBI yang memiliki unit produksi aktif seperti pada Tabel 1. 
Tabel 1. Sampel Penelitian

\begin{tabular}{|c|l|l|}
\hline No & \multicolumn{1}{|c|}{ SMK } & \multicolumn{1}{c|}{ Program Keahlian } \\
\hline 1 & $\begin{array}{l}\text { SMKN 2 Jetis } \\
\text { Yogyakarta }\end{array}$ & $\begin{array}{l}\text { a. Teknik Kendaraan Ringan } \\
\text { b. Teknik Bangunan dan Survei pemetaan } \\
\text { c. Teknik Instalasi Listrik Tenaga } \\
\text { d. Teknik Komputer Jaringan dan Multi media }\end{array}$ \\
\hline 2 & $\begin{array}{l}\text { SMKN 2 Depok } \\
\text { Sleman }\end{array}$ & $\begin{array}{l}\text { a. Teknik Permesinan } \\
\text { b. Teknik Gambar Bangunan } \\
\text { c. Teknik Otomasi industri } \\
\text { d. Teknik Komputer Jaringan }\end{array}$ \\
\hline 3 & $\begin{array}{l}\text { SMKN 2 Pengasih } \\
\text { Kulon Progo }\end{array}$ & $\begin{array}{l}\text { a. Teknik Kendaraan Ringan } \\
\text { b. Teknik Konstruksi Kayu }\end{array}$ \\
\hline 4 & $\begin{array}{l}\text { SMKN 2 Wonosari } \\
\text { Gunung Kidul }\end{array}$ & $\begin{array}{l}\text { a. Teknik Permesinan } \\
\text { b. Teknik Arsitektur Bangunan } \\
\text { c. Teknik Komputer Jaringan }\end{array}$ \\
\hline
\end{tabular}

Variabel dalam penelitian ini meliputi: context, input (fasilitas praktek, program unit produksi, kemampuan guru, siswa, dan teknisi), process (KBM, produksi), product (kompetensi kerja, kualitas barang), dan outcome (dampak bagi sekolah).

Pengumpulan data kuantitatif melalui kuesioner, lembar penilaian dengan skala Likert 1-4 dan 1-5 dan dokumetasi. Langkah penyusunan instrumen: (1) merumuskan kisi-kisi instrumen; (2) uji coba instrumen; dan (3) uji validitas dan reliabilitas instrumen.

Pengumpulan data kualitatif dilakukan dengan wawancara mendalam semi terstruktur dan melalui observasi. Uji reliabilitas pedoman wawancara dengan cara (a) mengecek apakah pedoman wawancara dan observasi tidak mengandung keraguan serta kesalahan; (b) konsistensi antara kode, dan definisi; (c) berkoordinasi dan mengkomunikasikan 
diantara anggota dan sharing data; dan (d) mengadakan cross chek dengan peneliti lain (Creswel, 2009). Uji validitasnya dengan cara: (a) triangulasi; (b) member checking, dan (c) use rich, thick description.

Selain itu untuk menjaga keabsahan data dengan cara: a) peneliti sebagai instrumen utama; (b) subyek wawancara dari berbagai sumber; (c) menggunakan alat bantu perekam suara; (d) wawancara dilakukan pada sekelompok subyek; (e) menjaga kondisi dan situasi wawancara secara alamai dan; (f) cross chek hasil wawancara.

Analisis data dilaksanakan dengan tiga cara yaitu: (1) analisis data kuantitatif dengan menggunakan statistik deskriptif untuk melihat kecenderungan kategori setiap variabel, (2) analisis data kualitatif dengan menggunakan model Miles dan Huberman (1984) yaitu: data reduction, data display dan conclusion drawing/ verification., dan (3) analisis data gabungan menggunakan logical framework analysis (LFA).

\section{Hasil Penelitian dan Pembahasan}

\section{Unit Produksi SMKN 2 Jetis Yogyakarta}

Unit produksi yang aktif ada empat dari sembilan unit produksi yang ada di program keahlian yaitu: Teknik Instalasi Tenaga Listrik, Teknik Bangunan (Teknik Bangunan Gedung dan Teknik Survei Pemetaan), Teknik Kendaraan Ringan, Teknik Komputer dan Jaringan serta Teknik Multi Media. Teknik kendaraan ringan tergolong unit produksi yang aktif mencari pasar produk seperti mendatangi sekolah-sekolah, kantor, instansi untuk promosi, namun sambutan dari konsumen belum positif. Adapun unit produksi yang lain belum melakukan upaya promosi yang memadai baru sebatas kolega guru, tetangga atau karena sudah dikenal memiliki perlengkapan memadai untuk dapat disewa (teknik survei pemetaan).

Komponen input sebagian besar sudah memenuhi standar minimal untuk dapat digunakan dalam kegiatan produksi/jasa, namun masih belum bisa mengikuti kemajuan teknologi (teknik kendaraan ringan). Selain itu semua unit produksi belum memiliki program kerja terjadwal dan tidak kontinyu, sehingga kegiatan unit produksi aktif bila ada pesanan pekerjaan. 
Proses produksi dilakukan oleh guru, teknisi dan siswa, namun hanya terbatas pada 1-2 guru, 1 teknisi dan 5-10 siswa. Hal ini dikarenakan keterbatasan pesanan produk/jasa. Walaupun demikian unit produksi sesungguhnya mampu manjadi tempat pelatihan kerja untuk meningkatkan keterampilan guru dan siswa. Kontrol pekerjaan dan finishing dilakukan oleh guru untuk menjaga kualitas produk/jasa.

Produk/jasa yang dihasilkan memiliki kualitas kategori baik dalam hal konstruksi dan bahan baku, dengan harga/tarif standar. Pelaksanaan kegiatan unit produksi mampu meningkatkan kesejahteraan warga sekolah, tetapi terbatas hanya pada 2-3 orang. Oleh karena kegiatan unit produksi tidak kontinyu, volume pekerjaan relatif kecil sehingga keuntungan yang diperoleh relatif kecil serta belum mampu menjadi sumber pembiayaan sekolah. Demikian halnya dengan jalinan kerjasama dengan industri belum ada, kecuali program keahlian survei pemetaan yang mampu menjalin kerja sama dengan industri dalam persewaan alat-alat survei pemetaan. Konsumen produk jasa baru sebatas untuk keperluan sekolah sendiri, guru, kolega guru, dan siswa.

\section{Unit Produksi SMKN 2 Depok Sleman}

Unit produksi yang aktif adalah (a) Teknik Otomasi Industri; (b) Teknik Komputer dan Jaringan; (c) Teknik Mesin Produksi dan Fabrikasi; (d) Teknik Gambar Bangunan. Unit produksi sebagian besar bergerak dalam produksi barang, kecuali teknik otomasi industri yang kadangkadang menerima jasa pemasangan instalasi, persewaan LCD dan genset. Sambutan konsumen cukup baik untuk UP Teknik Komputer Jaringan dan Teknik Mesin. Kendala yang dihadapi masih sulit memasarkan produk dan sebagian SDM masih sulit kerjasama untuk mengaktifkan unit produksi. Selain itu sebagian besar guru memiliki jam mengajar cukup padat (lebih 24 jam).

Sarana prasarana yang dimiliki telah memenuhi syarat untuk digunakan dalam kegiatan unit produksi, kecuali teknik otomasi industri yang kadang-kadang masih pinjam program keahlian lain. Unit produksi yang memiliki program kerja aktif adalah Teknik Komputer Jaringan dan 
Teknik Mesin, sedangkan unit produksi yang lain bersifat insidental pada saat ada pesanan.

Proses pelaksanaan pekerjaan dilakukan terbatas oleh 2-10 siswa dengan demikian siswa yang melaksanakan pembelajaran secara langsung jumlahnya terbatas. Namun unit produksi TKJ dapat mencakup semua siswa dengan sistem penjadwalan, mulai dari penerimaan barang hingga pengiriman barang. Pengontrolan pekerjaan dan finishing dilakukan langsung oleh guru, kecuali TKJ yang melakukan siswa dan guru.

Kualitas produk/jasa dari segi konstruksi, bahan baku serta pelayanan termasuk dalam kategori baik dengan harga mampu bersaing. Semua unit produksi mampu menjadi tempat pelatihan keterampilan guru dan siswa dengan jumlah terbatas yaitu 5-10 siswa, dan 1-2 guru, kecuali TKJ yang mampu untuk semua siswa. Demikian halnya dengan peningkatan kesejahteraan warga sekolah terbatas pada 2-3 guru dan karyawan. Keuntungan yang diperoleh unit produksi TKJ, Teknik Mesin dan Teknik Bangunan relatif besar dan memberi sumbangan pendapatan cukup besar pada sekolah, kecuali Teknik Otomasi Industri yang omsetnya relatif kecil.

Kepercayaan industri/masyarakat terhadap unit produksi dalam bentuk pemanfaatan produk, pemakaian jasa, pemasok bahan baku dan seleksi masuk karyawan baru.

\section{Unit Produksi SMKN 2 Wonosari Gunung Kidul}

Unit produksi yang aktif ada tiga yaitu: Teknik Permesinan, Teknik Bangunan (Arsitektur Bangunan), dan Teknik Komputer Jaringan. Kendala yang dihadapi lebih banyak pada pemasaran yang masih lemah, peraturan daerah tentang pemakaian sarrpras untuk kegiatan bisnis, ketersediaan waktu bagi guru, kapasitas produksi dan lain sebagainya.

Secara keseluruhan komponen input telah memenuhi syarat untuk melaksanakan kegiatan unit produksi, namun program kerja masih belum bisa berjalan secara kontinyu (kecuali Teknik Mesin). Pelaksana proses produksi adalah guru, siswa dan teknisi namun dengan jumlah terbatas (2-3 
guru, 1 teknisi, dan 5-10 siswa). Kontrol produksi dan finishing dilakukan oleh guru atau tukang.

Kualitas produk jasa yang dihasilkan telah memenuhi standar, dengan harga mampu bersaing dengan produk sejenis. Secara keseluruhan unit produksi yang ada mampu menjadi tempat meningkatkan keterampilan siswa, namun jumlahnya terbatas pada 5-10 siswa, 1-2 guru Teknik Bangunan, Teknik Mesin, 4-5 guru Teknik Komputer Jaringan. Namun demikian unit produksi TKJ mampu menjadi tempat pelatihan eksternal.

Secara keseluruhan sumbangan untuk pembiayaan operasional sekolah relatif masih kecil. Demikian halnya dalam peningkatan kesejahteraan warga sekolah masih terbatas pada beberapa guru dan karyawan yang terlibat langsung, sedangkan guru dan karyawan yang tidak terlibat mendapat pembagian keuntungan relatif kecil. Kerjasama dengan instansi dan industri masih terbatas dalam hal pelatihan karyawan di UP TKJ, pemakaian produk UP TM dan TB.

\section{Unit Produksi SMKN 2 Pengasih Kulon Progo}

Unit produksi dalam kondisi aktif ada dua yaitu Unit Produksi Teknik Kendaraan Ringan (Teaching Factory) dan Unit Produksi Bangunan (TKK). Kedua unit produksi tersebut tergolong aktif dan selalu ada kegiatan pekerjaan. Permasalahan yang menonjol pada pemasaran produk yang harus terus dilakukan dan persaingan bisnis dengan perusahaan sejenis. Teaching factory TKR termasuk terkenal di kota Wates sebagai bengkel terlengkap dengan pelayanan terbaik. UP TKK sudah dikenal masyarakat dan perusahaan yang menghasilkan produk berbagai jenis mebel dan konstruksi bangunan.

Secara keseluruhan kedua unit produksi tersebut memiliki komponen input dalam kategori baik dan telah dioptimalkan untuk proses produksi/jasa. Pelaksana proses produksi jasa semua siswa kelas XI (Teknik Kendaraan Ringan), sedangkan UPJ TKK terbatas pada 2-5 siswa. Kontrol hasil produk dan finishing oleh guru (TKK), sedangkan kontrol jasa TKR oleh siswa tetapi pengujian akhir dilakukan oleh kepala mekanik. 
Kualitas produk jasa sesuai standar, harga dan tarif jasa sesuai standar umum. Peningkatan kemampuan keterampilan terjadi pada semua siswa TKR, sedangkan pada TKK terbatas pada 5-10 siswa (TKK). Demikian halnya dengan peningkatan kesejahteraan warga sekolah terbatas 2-3 guru dan teknisi yang terlibat langsung. Sedangkan bagi guru dan karyawan yang tidak terlibat mendapat bagian keuntungan relatif kecil.

Teaching factory telah mampu menjadi tempat belajar semua siswa TKR bahkan mampu menjadi tempat praktek kerja bagi siswa sekolah lain. Kerjasama dengan industri dalam hal pemakaian jasa dan produk (kusen, mebel), sedangkan TKR mampu menarik konsumen dari instansi pemerintah/swasta yang memiliki armada transportasi.

Pembahasan

Kemampuan Program Keahlian di SMK dalam Mengembangkan Faktor Pendukung dan Mengatasi Kendala-Kendala dalam Pelaksanaan Unit Produksi

Implementasi unit produksi dapat dikelompokkan menjadi tiga golongan yaitu: (1) mampu menjadi sarana pembelajaran bagi siswa dan guru dan mampu memberi dukungan operasional sekolah (2 unit produksi atau $15,4 \%$; (2) belum mampu menjadi sarana pembelajaran bagi semua siswa dan guru tetapi mampu memberi dukungan operasional (5 unit produksi atau 38,4\%); dan (3) aktif tetapi belum mampu menjadi sarana pembelajaran bagi semua siswa dan guru serta belum mampu memberi dukungan operasional (6 unit produksi atau 46,1\%).

Unit produksi kelompok pertama mampu mengoptimalkan semua siswa dalam kegiatan dengan membuat jadwal khusus dan menjaga kelangsungan kerja unit produksi dengan melaksanakan berbagai upaya promosi. Unit produksi kelompok ke dua mampu membuat unit produksi selalu mendapatkan pekerjaan tetapi dalam pelaksanaan pekerjaan hanya memilih siswa tertentu untuk aktif. Unit produksi kelompok ketiga merupakan unit produksi yang keaktifannya pada saat tertentu saja, dan hanya memilih siswa tertentu saja. 
Kemampuan Mengelola Input untuk Pelaksanaan Unit Produksi

Pemanfaatan fasilitas praktek dan bahan baku sebagian besar unit produksi sudah maksimal aktif, namun dalam pemanfaatan program kurikulum, kemampuan guru, siswa dan teknisi belum maksimal, karena hanya memilih siswa tertentu saja $(84,6 \%)$, sehingga sebagian besar unit produksi belum mencapai tujuan.

Penyebab program kegiatan unit produksi belum dapat berjalan secara kontinyu adalah: (a) belum dapat membuat program yang selaras antara praktek siswa dan pelayanan produk/jasa pada konsumen, (b) lemahnya manajemen pemasaran, (c) motivasi tenaga pengajar untuk mengembangkan unit produksi masih lemah, (d) kesulitan mendapatkan peluang pangsa pasar, dan (e) kekawatiran terhadap Peraturan Pemerintah Daerah tentang pemanfaatan barang milik negara untuk kegiatan bisnis belum ada petunjuk pelaksanaannya.

Wadah Peningkatan Pengetahuan dan Keterampilan bagi Guru dan Siswa

Proses belajar di unit produksi merupakan kegiatan praktek yang menghasilkan barang/jasa, sehingga kegiatan belajar yang terjadi meliputi perencanaan, pelaksanaan, kontrol produk/jasa, evaluasi pekerjaan dan pemasaran hasil produk/jasa. Hal ini sesuai dengan teori experiential learning Kolb (Kolb, Boyatzis, dan Mainemelis, 1999: 2) yaitu dalam lingkaran lingkaran proses melihat, merasakan, mencari, mengasimilasi antara observasi dengan pikiran, dan berfikir dengan dua model yaitu (1) pada perencanaan yang sifatnya membuat desain pelaksananya guru (sebagian kecil siswa), (2) perencanaan yang bersifat jasa identifikasi permasalahan dilaksanakan siswa.

Proses selanjutnya dari teori experiential learning Kolb adalah dorongan untuk melakukan aktivitas pemahaman sebagai langkah awal melakukan pekerjaan. Pelaksanaan proses ini ada dua yaitu: (1) memberi pelatihan terlebih dahulu untuk mengenal permasalahan, (2) pembelajaran dilaksanakan langsung ditempat kerja.

Akhir dari lingkaran experiential learning Kolb menyelaraskan antara fikiran dan perasaan bahwa apa yang telah dikerjakan dari awal hinggaakhir 
telah memberikan pengalaman nyata, sehinggabila menghadapi pekerjaan yang sejenis tidak mengalami kesulitan dan kualitasnya meningkat. Serangkaian urutan kerja tersebut sesuai dengan teori situated cognition dan situated learning.

Unit Produksi sebagai Sarana Pembelajaran dan Kewirausahaan yang Efektif bagi Siswa

Keefektifan kegiatan unit produksi dapat di bagi menjadi dua yaitu: (a) keefektifan dalam penyelenggaraan unit produksi sesuai dengan kegiatan di industri yang didalamnya ada kegiatan proses belajar mengajar sesuai dengan situasi dan kondisi, (b) keefektifan kedua ditentukan seberapa banyak siswa yang dapat mengakses kegiatan unit produksi sebagai sarana belajar dan berwirausaha. Program dikatakan efektif apabila kegiatan program mencapai target yang ditetapkan (Thompson, 2008:3), dalam hal ini tujuannya sebagai sarana pembelajaran dan kewirausahaan bagi siswa dan guru .

Keefektifan pertama secara keseluruhan unit produksi mampu menjadi sarana belajar yang efektif bagi siswa dan guru, karena secara langsung siswa dan guru belajar menghadapi permasalahan kerja yang sesungguhnya. Kriteria keefektifan kedua yaitu jumlah siswa dan guru yang terlibat dalam kegiatan unit produksi belum tercapai.

Efektivitas pendidikan kewirausahaan di unit produksi disebut efektif apabila kegiatan seperti pembiasaan dalam merencana, proses produksi, dan pelaksanaan pemasaran hasil produk/jasa. Hasil penelitian menunjukkan bahwa tidak semua proses kegiatan tersebut dapat dilaksanakan oleh siswa, seperti dalam perencanaan dan pemasaran produk lebih banyak dilakukan oleh pengelola unit produksi.

Tingkat Daya Saing Produk Unit Produksi

Produk jasa yang dihasilkan unit produksi adalah barang atau jasa yang dapat dimanfaatkan oleh konsumen. Produk jasa yang dihasilkan semua unit produksi telah memenuhi standar umum dan memiliki kualitas lebih baik dari segi konstruksi dan bahan baku, tetapi penampilan masih 
belum bisa seperti yang dihasilkan industri. Selain itu jasa beberapa unit produksi sudah dikenal dengan hasil dan pelayanan memuaskan konsumen.

Berdasarkan harga jual atau tarif jasa yang ditetapkan sebagian lebih rendah dan sebagian lebih tinggi dibandingkan harga/tarif pasar pada umumnya. Demikian halnya kualitas pelayanan pada konsumen sudah memenuhi standar dan memuaskan konsumen.

Dampak Unit Produksi pada Sekolah dan Warga Sekolah

Pengelolaan keuntungan unit produksi dengan cara sebagai berikut: $60 \%$ untuk unit produksi program keahlian dan $40 \%$ untuk unit produksi pusat (sekolah). Dari 60\% yang diterima unit produksi Bengkel diperinci sebagai berikut: 10\% tambah modal, 22\% perawatan, 24\% kas Bengkel, dan 4\% administrasi, sedangkan 40\% unit produksi sekolah untuk: 15\% kesejahteraan umum, 10\% biaya listrik, 10\% kas, 2,5\% administrasi dan $2,5 \%$ penyusutan.

Berdasarkan hal itu kontribusi yang diberikan unit produksi adalah pemasukan biaya operasional sekolah, namun jumlahnya masih relatif kecil. Guru dan karyawan yang terlibat langsung (hanya 2-3 orang) dalam pelaksanaan unit produksi mendapat honorarium sesuai dengan tugas dan tanggung jawabnya. Bagi guru dan karyawan yang tidak terlibat langsung, pada umumnya mendapat tambahan tunjangan hari raya dan snack di jurusan. Namun demikian dampak yang besar adalah menambah pengalaman kerja yang sesungguhnya bagi siswa dan guru, sehingga meningkatkan kemampuan komptensi kerjanya.

Dampak Unit Produksi terhadap Tingkat Kepercayaan Industri dan Masyarakat

Kepercayaan industri dan masyarakat terhadap kegiatan unit produksi adalah dengan melakukan kerjasama dalam produksi/jasa. Hasil penelitian menunjukkan ada tiga jenis kerjasama yaitu: (a) kerjasama dalam proses produk dan jasa, (b) kerjasama dalam pemanfaatan produk jasa unit produksi, dan (c) kerjasama dalam pelatihan. 
Bentuk lain kepercayaan industri terhadap sebagian besar SMKN adalah dipercaya dalam menyelenggarakan tes masuk penerimaan tenaga kerja di industri, kemudahan mendapat tempat praktek kerja industri dan kemudahan mendapatkan pekerjaan setelah lulus. Bentuk kerja sama lain adalah pemesanan secara langsung dari masyarakat, sehingga menjadikan SMK lebih dikenal oleh masyarakat.

\section{Simpulan}

1. Sebagian besar unit produksi di SMKN RSBI-SBI aktif, namun sumbangan sebagai sarana pembelajaran siswa dan guru, serta sebagai sumber biaya operasional relatif kecil

2. Sebagian besar unit produksi mampu menyelaraskan antara program kurikulum dan program unit produksi, namun pemanfaatan sarana dan prasarana serta sumber daya manusia (siswa, teknisi dan guru) belum optimal

3. Peningkatan pengetahuan dan keterampilan melalui belajar dengan konsep teori situated cognition, situated learning, teori belajar constructivism dan experiential learning kolb tercapai, namun terbatas pada sebagian kecil siswa

4. Keefektifan penyelenggaraan unit produksi sebagai sarana pembelajaran tercapai, namun jumlah siswa dan guru yang terlibat relatif kecil

5. Kualitas konstruksi dan bahan baku produk unit produksi tinggi dengan harga jual sesuai standar, namun kualitas tampilan belum sebaik produk pabrik

6. Unit produksi mampu menambah kesejahteraan guru dan karyawan di SMK, namun jumlahnya relatif kecil.

7. Sebagian besar unit produksi dipercaya masyarakat dan industri melalui kerjasama proses produksi/jasa, pemanfaatan produk/jasa, pelatihan tenaga kerja dan proses penerimaan tenaga kerja. 


\section{Daftar Pustaka}

Almasdi Syahza. 2006. Model pengembangan wajib belajar 12 tahun di kabupaten Bengkalis propinsi Riau. Diambil pada tanggal 25 Juli 2012 dari http//www.almasdi.dikti.net

Creswell, John W. 2009. Research design, qualitative, quantitative, and mixed methods approaches. Los Angeles. Sage.

Kolb, D.A., Richard E.B., Charalampos, M. (1999). experiential learning theory: Previous Research and New Directions.

Direktorat Pembinaan SMK. 2006. Penyelenggaraan sekolah menengah kejuruan bertaraf internasional. Jakarta: Direktorat Pembinaan SMK Direktorat Jenderal Manajemen Pendidikan Dasar dan Menengah Departemen Pendidikan Nasional.

Direktorat Pendidikan Menengah Kejuruan. 2005. Kebijakan Pendidikan Menengah Kejuruan 2005-2009. Direktorat Jenderal Pendidikan Dasar Dan Menengah Depertemen Pendidikan Nasional.

Joko Sutrisno. 22 Mei 2009. Sekolah kejuruan untuk mencetak enterpreuner. Diambil pada tanggal 20 Maret 2010 dari http//www.news.php.htm

Martubi \& Satunggalno. 1998. Model-Model Penyelenggaraan Unit Produksi di Sekolah Menengah Kejuruan daerah Istimewa Yogyakarta. Diambil pada tanggal 16 Maret 2010 dari http://uny.ac.id/dosen.

Neumark, D. Ann, A. 2003. What do we know about the effects of school-to-work. Case study of Michigan. Journal of Vocational Education Research, volume 28(1), pp 59-84. Th 2003.

Silvi Intriani. 2009. Peran unit produksi sebagai media belajar berwirausaha bagi siswa kelas X di SMK Cor Jesu Malang. Diambil pada tanggal 20 Mei 2012 dari http://library.um.ac.id.

Slamet PH. 2008. Desentralisasi pendidikan di Indonesia. Jakarta: Depdiknas.

Sri Lestari. 2010. Model Pengelolaan Unit Produksi di Sekolah Menengah Kejuruan. Diambil pada tanggal 20 Maret dari http://digilib.uns.ac.id. 
Subiyanto. (2008). Pelaksanaan kewirausahaan melalui unit produksi di sekolah menengah kejuruan negeri 3 Ciamis. Diambil pada tanggal 27 November 2010 dari http//www. Subiyanto. Html

Suyanto. 14 Mei 2010. 3000 Lowongan Pekerjaan untuk Lulusan SMK. Diambil pada tanggal 14 Mei 2010 dari http//www. Detik. Com

T Fsimbolon. 2009. SDM Rendah Penyeabab Lambatnya Pembangunan. Diambil pada tanggal 7 Mei 2010 dari http://www.waspada.co.id/

Wardiman Djoyonegoro. 1998. Pengembangan sumber daya manusia, melalui sekolah menengah kejuruan (SMK). Jakarta. PT. Jayakarta Agung Offset. Badan Penelitian dan Pengembangan 